\title{
The social integration of Māori prisoners
}

\section{Kim Workman}

Kim Workman (Ngati Kahungunu and Rangitaane) is a retired public servant, who is the founder and strategic adviser to the Rethinking Crime and Punishment project. He is an Adjunct Research Fellow at the In statute of Criminology, Victoria University of Wellington. This is a paper presented at the Deakin University Reintegration Puzzle Conference, Crowne Plaza Hotel, Auckland on 22nd August 2013.

\section{Introduction}

Kei ngā rangatira, e ngā mana, e ngā reo, e ngā maramara kohinga o te ao, tēnei ka mihi! Tēnā Koutou, tēnā tātou katoa!

The preparation of this paper, was stimulated by memory of an incident that happened within our hapū in the 1950s. The Secretary/Treasurer of a local marae (let's call him Anzac) was discovered to have defaulted with the entire building fund, a not inconsiderable sum. He had been having dreams about which horses were going to win the following Saturday, and persuaded himself that this was an easy way to increase the fund. After about six months, he realised that they were not horses, but nightmares. The horses were still running, but the building fund was no more. In repentance, he handed himself over to the Police, and served three months in Mt Crawford Prison.

It was what happened next that was interesting. On his return home, the local marae committee held a pōwhiri (a welcome home) ceremony, celebrated with a hākari (feast), and immediately reinstated him as Secretary/Treasurer of the Committee. The local pākehā were astounded, and in some cases, outraged. We were referred to as 'those stupid Mãori'. In response to the generosity and grace of his whānau and hapu, the ex-offender gave up his job, worked his guts out fundraising and had the building fund restored to its original level within a year.

\section{Tikanga Māori and the criminal justice system}

That story, for me, demonstrates the influence of tikanga Māori on prisoner reintegration.

Space and time constraints do not permit a full discussion on traditional means of addressing wrongdoing. In very basic terms, a spiritual violation occurs (breach of tapu) through wrong doing (hara), which affects the reputation, prestige, charisma (mana) of a person, or a collective of people. That wrongdoing requires rectification (utu), through some form of reciprocal response (utu) in order to restore balance to the community (whakahoki

For a lengthy discussion on the dynamics and process of dispute resolution in traditional Māori society, see Tomas \& Quince (1998). 
mauri) (Paterson, 2005, pp. 116-135). People were expected to act in ways that strengthened and maintained relationships; these connections were strengthened by the principle of whanaungatanga, or familial obligations. ${ }^{1}$

I want to consider this case study as a traditional Maori response to offending, and consider some of the reasons why there has been an uneasy alignment in the way Maori approach the social integration of offenders, and that taken by the modern criminal justice system.

\section{The principle of rehabilitation}

Does the concept of 'whakahoki mauri' align in any way with the pākehā concept of 'rehabilitation.'? It used to. The traditional meaning of rehabilitation was ultimately concerned with the shaping of a person's capability and capacity to play a full part in society (McNeill, 2012). The French term 'rétablir dans ses droits' captures the essence of rehabilitation as being about the full restoration to the former offender of all rights and responsibilities (McWilliams \& Pease, 1990; Lewis, 2005, pp. 119-135).

In recent times however, rehabilitation has been recast not as an end but as a means or a mechanism for reducing crime (Garland, 2001; Robinson \& McNeill, 2004). In our case study, Anzac did not have to wait indefinitely to convince people that he would be unlikely to reoffend. He is firmly placed within the whānau and hapu construct, able to contribute his accounting and organisational skills, and empowered to make a difference in the community. All of that contributes to the likelihood that he will not reoffend; but that is not the goal. The goal which was achieved swiftly, was to integrate him back into the community in order to move toward the restoration of community well-being and peace.

The Scottish criminologist Fergus McNeill considers that pursuing rehabilitation as a means of protecting the public and reducing reoffending is counter-productive (Wilkinson \& Pickett, 2009). If we want to achieve safer communities, then we need socially integrated citizens. The role for those involved in prisoner reintegration is, therefore, not only about reducing reoffending. It is equally important to work toward the restoration of whanau and community peace, and ensure that former offenders can access the same social goods and resources as other law-abiding members of the community. This approach recognises that former prisoners regularly face unequal treatment and stigmatisation - and usually face a raft of other social problems

\section{The principle of public safety}

These days, we reduce reoffending in the pursuit of 'public safety'. But the prevailing view of public safety comes from the recognition that persons arrested and sentenced to prison are not randomly selected from our society. They are disproportionately poor, disproportionately Māori, and with disproportionate health, addiction and mental health conditions. They also have poor educational and employment skills, marginal housing, and are more likely to come from violent neighbourhoods and dysfunctional families and whanau. They are publicly perceived as an underclass, presenting a safety risk to the law-abiding community.

The contemporary preoccupation with risk - and the obsession with finding someone to blame when risks materialise - puts the management and reduction of risk as a high priority. 
There is, however, another, broader view of what constitutes public safety, one that is embraced within the concept of 'whakahoki mauri' - of restoring community peace and balance. In that scenario, the functioning of a community is measured by a collective sense of well-being, and beyond the aggregation of individual behaviour (Smith, 1999).

In crime reduction efforts with high-crime communities, e.g. parts of South Auckland, the cycle of removal to and return from prison, has so weakened the social networks and institutions that prevent crime, that crime rates actually increase (Clear, Waring, \& Scully; 2003). In that scenario, prison becomes a major cause of crime, and long-term public safety is jeopardised.

Thus far, I have argued that the way we define rehabilitation and the way we think about public safety is out of alignment with the tikanga concept of 'whakahoki mauri'. Is there anything then, that it aligns with?

It seems to me that there is - that there are some synergies between whakahoki mauri and the theory of 'desistance'. But before we considering that issue, let's consider the characteristics of Maori prisoners, and the nature of those prisoners that are leaving the prisons today.

\section{Characteristics of Māori prisoners}

A 2010 study involving 217 Māori prisoners (129 men and 88 women) showed that Māori prisoners have a higher level of recidivism than non-Maori, and respond less well to existing rehabilitation programmes. Of the Māori men surveyed, $48 \%$ were on their fourth or subsequent prison sentence, providing support for the argument that prison strips Māori communities of their young men, often for extended periods (Gordon \& MacGibbon, 2011).

There were also strong signs of intergenerational recidivism among the Māori sample. Two-thirds of that sample had seen someone they lived with as a child go to prison, compared to one-third of non-Māori. The most likely relatives to have been imprisoned were, in order, father, uncle, brother, cousin and mother. Around half of the sample had visited prison as children, most on multiple occasions.

The prison population is aging. In 1980, prisoners aged 30 years and over made up 20\% of the sentenced population; they now comprise over $61 \%$ of the total. The increase in the average age of prisoners is likely to be due to the longer times being served in prison and a change in the types of offences committed. Also, recidivist offenders appear to be coming to prison more often and staying longer (Department of Corrections, 2011). All the above factors combine to present a depressing scenario in which significant numbers of Māori recidivist offenders, aged 30 plus, are being released in to the community. For the most part, they fail to socially integrate.

\section{About desistance theory}

Given this pessimistic scenario, what does desistance theory have to offer?

'Desistance' refers to the process by which, with or without the intervention of criminal justice agencies, offenders terminate their offending activities and maintain crime-free lives. 
What does this theory have to offer?

First, it distinguishes between primary desistance, i.e. the cessation of offending, and secondary desistance, i.e. a change in the way that an ex-offender seems him or herself (Maruna \& Farrall, 2004, pp. 171-194).

Secondary desistance is about ceasing to see yourself as an offender and finding a more positive identity; it is about successfully peeling off the criminal label that criminal justice systems are so effective at applying. This approach is essential for those who have entrenched criminal identities (Bottoms, Shapland, Costello, Holmes, \& Muir, 2004; Laub \& Sampson, 2003). It is about the internalisation of change and the fundamental redirection of the ex-offender's life. As such it also represents the most secure basis of public protection because the ex-offender has changed in a lasting way, a way that will endure long after short-term controls and constraints have been removed.

Second, it values the idea of hope. The focus is on supporting offenders to see themselves in a new and more positive light, with hope for the future. Positive outcomes are more likely to be achieved when interventions and services are inspired by a 'strength-based' approach to make use of personal and community assets in order to help offenders face personal challenges and successfully reintegrate into the community (Maruna \& LeBel, 2002, pp. 158-180). Given the above, it is not surprising that hope plays a key part in these processes (Burnett \& Maruna, 2004; Farrall \& Calverley, 2006). Desistance can be provoked by someone believing in the offender; someone who carries hope and keeps it alive when the offender cannot do so for him or herself.

Third, it promotes the idea of 'social capital' as well as 'human capital'. The emphasis is not only on human capital i.e. on the individual and their capacity to address personal needs, such as drug and alcohol dependency, but on developing social capital, including employment, whānau and community support (Pitts, 2010, pp. 3ff).

Fourth, it recognises that change occurs over a period of time (United Nations, 2012). Programmes based on desistance theory emphasise long-term change over short-term control, and recognise that progress is unlikely to be direct or continuous. It also understands that getting there can be very difficult. The process of desistance, for those who have developed persistent offending patterns, is typically characterised by ambivalence and vacillation (Burnett, 1992; Burnett, 2000; Burnett, 2004). It is not an event, it is a process; a process of 'to-ing' and 'fro-ing', of progress and setback, of hope and despair. It also understands that some offenders may never change.

Finally, and for many ex-offenders, desistance is about personal redemption; not necessarily in the spiritual or theological sense but rather in the sense of finding a way to 'make good' for a troubled and troubling past by making a positive contribution to families or communities now (Maruna, 2001).

\section{Whakahoki mauri - Anzac's case}

There are some key similarities between Anzac's case, in which the ultimate intention was to restore him to his original place within the community, and the thinking behind desistance theory. 
First, there was a presumption that the offender had been adequately punished, and was rehabilitated. The welcome home, the ritual of de-stigmatisation, the reinstatement, stripped him of any criminal label that he or others might have attached.

Second, from the day that he was released, Anzac's life was filled with hope; he knew that his whānau and hapu had belief in him, he was in control of his own destiny from that point on - he had 'agency' over his own life.

Thirdly, the expectation was that his personal human capital, i.e his bookkeeping and organisational skills, were valued and he was expected to use them to the benefit of the wider community, and to develop and contribute to the social capital of the wider community.

Fourthly, he was given the opportunity to 'make good', to go through a process of redemption. Community acceptance, in his case, occurred prior to redemption; in the mainstream system, it is more likely that things will work the other way around, i.e. offenders are given the opportunity for public redemption, following a long period of community surveillance and ultimate acceptance.

What was it that upset pākehā mostly about this case? It was the apparent failure to recognise that there was a public safety risk. The identification and acknowledgement of risk presents whānau with a paradox. When we choose to define whānau members as a risk and undertake to manage them as a risk, in order to protect the wider whānau and community, we confirm their existence as a threat, and legitimise and reinforce feelings of fear (Douglas, 1992). It also, of course, exposes whānau to censure and 'I told you so' criticism, when there is an occasional and sometimes spectacular failure. The political cost of failure through a sentinel event is sometimes sufficient to invite public censure and withdrawal of official support (Robinson \& MacNeill, 2004).

\section{The Whānau imperative}

By way of contrast, the concept of 'whanaungatanga' stresses that we are all part of a collective of whānau - offenders included - and that as whānau, we have a mutual obligation to respond intelligently and rationally to our crime problems. Moreover, in some jurisdictions at least, the recognition that tackling crime requires that we nurture the collective efficacy of whanaungatanga recognises that we are also all part of the solution. In order for communities to be safer, they need to be stronger - together. In order to be stronger, communities also need to be fairer - as we learn (or fail to learn) from international affairs. Without justice there is no peace.

\section{A Kaupapa Māori approach to prisoner reintegration}

There is a fundamental difference between the way the criminal justice system conceptualises prisoner reintegration and the preferences of Māori. One of the reasons for the poor Māori recidivism rate is that it exists in a culture which wants to do things to people, whether or not they are willing subjects. Stemming from the compliance culture which permeates the criminal justice system, offenders are subjected to well-meaning decisions about what they need to do in their lives to 'put things right' (Farrall, 2002). 
A Māori prisoner reintegration strategy is more likely to:

- be based on kaupapa Māori values,

- fully engage whānau, the wider Māori community, Māori service providers and staff,

- align with the Government's whānau ora strategy,

- engage with Government outcomes beyond the justice sector,

- promote restorative practice.

\section{Strategies that reflect 'whakahoki mauri'}

The strengths-based narrative that is part of the whānau ora framework combats stigmatisation and negative imaging by deploying a range of strategies. They include:

- Providing opportunities for whānau members to make amends, demonstrate their value and potential, and make positive contributions to their communities (Pearl \& Riessman, 1965).

- Providing public recognition, including rituals of certification that symbolically 'de-stigmatise' the stigmatised person (Bazemore, 1999). The offender is transformed from a taker into a giver.

- Whānau members are encouraged to produce things the community wants, such as gardens, graffiti-free neighbourhoods, a less dangerous community and habitable housing for the homeless (Dickey \& Smith, 1998).

- Developing a role for 'wounded healers' (i.e. ex-offenders) as para-professionals, lay therapists or counsellors (Brown, 1991). Brown estimated that around three quarters of the counsellors working in the over 10,000 substance abuse treatment centres in the United States are former substance abusers themselves.

- Encouraging mutual efforts at reconciliation, where whānau members and society work together to make amends - for hurtful crimes and hurtful punishments - and move forward (Johnson, 2002).

- Nurturing behaviour is inconsistent with an anti-social lifestyle (Toch, 1975; Sampson \& Laub, 1993; Lanier \& Fisher, 1990). Roy Dunn, leader of the Notorious chapter of the Mongrel Mob puts it this way:

At the end of the day, I have been thinking, what's the meaning to life? There must be more to this, you know, there must be more to life. As a parent, a Rangatira, you have to look at all those angles, eh, and to me it was about - well, enough was enough. Keep going the way we are, we will live in the past and we will stay there. So, it was all about time to change. That was my vision. When I came out of jail, I was looking for people in the society to help direct and put me on that way, not for my journey but for our kids and our whānau. In the old days, it was about our patch, we couldn't see nothing else. But now, time's changed. It's time to build their future; not let them go down the paths we've been. 


\section{Conclusion}

This paper proposes that something other than the prevailing paradigm is required, for the social integration of Māori prisoners to be more successful. This approach would be based on traditional tikanga principles, and be directed not at reducing reoffending, but restoring peace and balance within the whanau and wider community, i.e. whakahoki mauri.

Such an approach would:

- reinstate the traditional meaning of rehabilitation, which was ultimately concerned not with the reduction of reoffending, but with shaping a person's capability and capacity to play a full part in society;

- consider the goal of public safety achieved, when community peace and balance is restored, and a collective sense of well-being is achieved;

- focus on assisting ex-prisoners to internalise change and establish a positive, pro-social identity, in the knowledge that a fundamental redirection of the ex-offender's life will endure long after short-term controls and constraints have been removed;

- increase emphasis on building social capital as well as human capital;

- place less emphasis on risk management, and more emphasis on building community support and cohesion; and

- recognise the fundamental role of whānau and whanaungatanga in the social integration of Māori prisoners.

\section{References}

Bazemore, G. (1999). After shaming, whither reintegration: Restorative justice and relational rehabilitation (pp. 155-194). In G. Bazemore \& L. Walgrave (Eds). Restorative juvenile justice: Repairing the harm of youth crime. Monsey, NY: Criminal Justice Press.

Bottoms, A., Shapland, J., Costello, A., Holmes, D., \& Muir, G. (2004). Towards desistance: Theoretical underpinnings for an empirical study. Howard Journal of Criminal Justice, 43(4): 368-89.

Brown, D. J. (1991). The professional ex-: An alternative for exiting the deviant career. The Sociological Quarterly, 32, 219-230.

Burnett, R. (1992). The dynamics of recidivism. Oxford: University of Oxford Centre for Criminological Research.

Burnett, R. (2000). Understanding criminal careers through a series of in-depth interviews.Offender Programs Report, $4(1), 1-16$.

Burnett, R. (2004). One-to-one ways of promoting desistance: In search of an evidence base. In R. Burnett \& C. Roberts (Eds). What works in probation and youth justice. Cullompton: Willan Publishing.

Burnett, R., \& Maruna, S. (2004). So 'prison works' does it? The criminal careers of 130 men released from prison under Home Secretary, Michael Howard. Howard Journal, 43(4), 390-404.

Clear, T. D., Waring, R. E., \& Scully, K. (2003). Co-ercive mobility and crime: A preliminary examination of concentrated incarceration and social disorganisation. Justice Quarterly, 20, 3364.

Department of Corrections. (2011). Offender Volumes Report.

Dickey, W. J., \& Smith, M. E. (1998). Dangerous opportunity: Five futures for community corrections: The report from the Focus Group. Washington, DC: U.S. Department of Justice, Office of Justice Programs.

Douglas, M. (1992). Risk and blame: Essays in cultural theory. London: Routledge

Farrall S. (2002). Rethinking what works with offenders: Probation, social context and desistance from crime. Cullompton: Willan Publishing.

Farrall, S., \& Calverley, A. (2006). Understanding desistance from crime: Theoretical directions in rehabilitation and resettlement. Maidenhead: Open University Press.

Garland, D. (2001). The culture of control: Crime and social order in contemporary society. Oxford: Oxford University Press.

Gordon, L., \& MacGibbon, L. (2011). A study of the children of prisoners: Findings from Māori data June 2011 (pp. 3-7). A report prepared for Te Puni Kōkiri, December 2011.

Johnson, R. (2002). Hard time, 3rd ed. Belmont, CA: Wadsworth. 
Lanier, C. S., \& Fisher, G. (1990). A prisoners' parenting center (PPC): A promising resource strategy for incarcerated fathers. Journal of Correctional Education, 41, 164.

Laub, J., \& Sampson, R. (2003). Shared beginnings, divergent lives: Delinquent boys to age seventy. Cambridge, MA: Harvard University Press.

Lewis, S. (2005). Rehabilitation: Headline or footnote in the new penal policy. Probation Journal, 52(2).

Maruna, S. (2001). Making good: How ex-convicts reform and rebuild their lives. Washington, DC: American Psychological Association.

Maruna, S., \& Farrall, S. (2004). Desistance from crime: A theoretical reformulation. Kvlner Zeitschrift fur Soziologie und Sozialpsychologie.

Maruna, S., \& LeBel, T. P. (2002). Revisiting ex-prisoner re-entry: A buzzword in search of a narrative. In S. Rex \& M. Tonry (Eds). Reform and punishment, pp. 158-80. Cullompton: Willan.

McNeill, F. (2012). What works and what's just. European Journal of Probation, 1(1), 2009, 21-40, www.ejprob.ro.

McWilliams, W., \& Pease, K. (1990). Probation practice and an end to punishment. Howard Journal of Criminal Justice, 29(1), 14-24.

Paterson, J. (2005). Exploring Maori values, pp. 116-135. Australia: Thomson Dunmore Press.

Pearl, A., \& Riessman, F. (1965). New careers for the poor: The nonprofessional in human service. New York: The Free Press.

Pitts, S. (2010). The effective resettlement of offenders by strengthening 'community reintegration factors', pp. $3 \mathrm{ff}$. Resource Material Series No. 82 (Tokyo, Asia and Far East Institute for the Prevention of Crime and the Treatment of Offenders, 2010), Work Product of the 145th International Training Course, Visiting Experts' Papers.

Robinson, G., \& McNeill, F. (2004). Purposes matters: The ends of probation. In G. Mair (Ed.). What matters in probation work. Cullompton: Willan.

Sampson, R. J., \& Laub, J. (1993). Crime in the making: Pathways and turning points through life. Cambridge, MA: Harvard University Press.

Smith, S. (1999). What future for 'public safety' and 'restorative justice' in community corrections? Sentencing and Corrections: Issues for the 21st Century, no. 11. Washington, DC: U.S. Department of Justice, National Institute of Justice, September.

Toch, H. (1975). Men in crisis: Human breakdowns in prisons. Chicago: Aldine.

Tomas, N., \& Quince, K. (1998). Maori disputes and their resolution. In Spiller, P. (Ed.) Dispute resolution in New Zealand, ch. 8. Auckland: Oxford University Press.

United Nations Office on Drugs and Crime. (2012). Introductory handbook on the prevention of recidivism and the social reintegration of offenders. United Nations.

Wilkinson R. G., \& Pickett, K.E. (2009). The Spirit level: why more equal societies almost always do better. London: Penguin - Allen Lane. 